\title{
EVALUASI PENERAPAN SISTEM KEUANGAN DESA (SISKEUDES) DI KECAMATAN KABILA
}

\author{
William Indra S. Mooduto, Herlina Karim \\ Universitas Bina Mandiri Gorontalo \\ Program Pascasarjana STIA Bina Taruna Gorontalo \\ william.mooduto@gmail.com
}

\begin{abstract}
ABSTRAK
Tujuan penelitian ini adalah: 1) untuk mengetahui penerapan Sistem Keuangan Desa (Siskeudes) di Kecamatan kabila Kabupaten Bone Bolango; 2) untuk mengetahui apa saja faktor penghambat dan faktor pendukung dalam penerapan sistem keuangan desa (Siskeudes) di Kecamatan Kabila.

Penelitian ini menggunakan pendekatan kualitatif dan jenis penelitian deskriptif dengan menggunakan teknik pengumpulan data melalui observasi, wawancara mendalam dan dokumentasi. Teknik analisis data dilakukan melalui tahapan reduksi data, penyajian data dan penarikan kesimpulan.

Hasil penelitian ini menunjukkan bahwa: 1) penerapan Sistem Keuangan Desa (siskeudes) membantu pemerintah desa dalam mengelola keuangan desa; 2) Sistem Keuangan Desa (Siskeudes) diterapkan pada tahun 2017;3) proses penggunaan aplikasi Sistem Keuangan Desa di Kecamatan Kabila sudah dilaksanakan secara terstruktur dan sesuai prosedur. Faktor yang mempengaruhi penerapan Sistem Keuangan Desa (siskeudes). Faktor penghambat yaitu kurangnya BIMTEK aparat desa, faktor pendukung yaitu memudahkan dalam pelaporan keuangan desa. Penerapan aplikasi Sistem Keuangan Desa (siskeudes) di Kecamatan Kabila sudah berjalan dengan baik. Dalam hal ini kualitas Sumber Daya Manusia (SDM) harus sangat di perhatikan karena dapat berdampak pada kualitas laporan keuangan yang akan di hasilkan.
\end{abstract}

Kata kunci: evaluasi, penerapan. siskeudes

\section{PENDAHULUAN}

Desa merupakan kesatuan hukum otonom dan memiliki hak dan wewenang untuk mengatur rumah tangganya sendiri. Undang-Undang Nomor 6 Tahun 2014. 2014 tentang Desa menjadi bukti ketegasan komitmen Pemerintah Indonesia dan anggota DPR-RI untuk melindungi dan memberdayakan desa. Sejak di tetapkannya Undang-Undang Nomor 6 Tahun 2014 tentang Desa, maka Pemerintah pusat, Pemerintah Daerah Provinsi, dan Pemerintah Daerah Kabupaten/Kota dapat melakukan penataan desa. Penataan sebagaimana dimaksud dalam Pasal 1 Undang-Undang No mor 6 Tahun 2014 tentang Desa berdasarkan hasil evaluasi tingkat perkembangan pemerintahan desa sesuai dengan ketentuan peraturan perundang-undangan.

Desa menurut Undang-Undang Nomor 6 Tahun 2014 tentang Desa Pasal 1 mengartikan desa sebagi berikut: "Desa adalah desa dan desa adat atau yang disebut de ngan nama lain, selanjutnya disebut Desa, adalah kesatuan masyarakat hukum yang memiliki batas wilayah yang berwenang untuk mengatur dan mengurus pemerintahan, kepentingan masyarakat setempat berdasarkan prakarsa masyarakat, hak asalusul, dan/atau hak tradisional yang diakui dan dihormati dalam sistem pemerintahan Negara Kesatuan Republik Indonesia.

Pemerintahan desa ruang lingkup pengelolaan keuangan desa meliputi perencanaan, pelaksanaan, penatausahaan, pela-

Submit: August $16^{\text {th }}, 2020 \quad$ Accepted: Sept. $5^{\text {th }}, 2020 \quad$ Published: Sept. $26^{\text {th }}, 2020$ Journal of Economics, Business and Administration (JEBA) - E-ISSN: 2746-1688 27 
poran, dan pertanggungjawaban keuangan desa, yang keseluruhannya diperuntukkan dalam memenuhi kebutuhan desa demi terwujudnya pembangunan keuangan desa yang didapatkan dari sumber pendapatan desa haruslah dikelola dengan baik demi tercapainya pembangunan desa. Melalui kebijakan dana desa, perekonomian dan kesejahteraan masyarakat diharapkan bisa meningkat.

Pengelolaan keuangan desa diperlukan adanya suatu transparansi dan akuntabilitas yang merupakan suatu bentuk keterbukaan pemerintah desa agar kinerja pemerintahan desa menjadi lebih baik. Jika laporan keuangan desa dapat dilaksanakan dengan baik, maka kinerja pemerintahan desa akan meningkat. Kenyataan yang terjadi saat ini terkait pengelolaan keuangan desa, secara prinsip masih banyak desa yang memiliki permasalahan terkait laporan keuangan desa ini, antara lain: 1) sering terjadi keterlambatan laporan keuangan dalam penyampaian dari desa ke kecamatan; 2) masih lemahnya skill (keterampilan) terkait kreativitas laporan keuangan; 3) masih lemahnya infrastruktur terkait teknologi informasi (internet); 4) dalam laporan keuangan yang dibuat oleh kepala desa selama ini masih bersifat konvensional (tradisional); 5) pengawasan dalam pengelolaan dana desa masih belum berjalan karena masih kurang transparan dengan masyarakat.

Di Kecamatan Kabila Kabupaten Bone Bolango terdiri dari 7 desa yaitu terdiri dari Desa Dutohe, Desa Dutohe Barat, Desa Tanggilingo, Desa Poowo, Desa Poowo Barat, Desa Talango, dan Desa Toto Selatan setiap desa terhitung memperoleh alokasi dana desa dalam jumlah yang cukup banyak, yakni sekitar 800 juta sampai 1 milyar. Besar dana yang dibagikan di setiap desa berbeda-beda, hal ini didasarkan pada luas wilayah, jumlah total penduduk, jumlah penduduk miskin, dan indeks kemahalan konstruksi serta indeks kesulitan geografis.

Diciptakanlah sebuah aplikasi bernama Sistem Keuangan Desa (Siskeudes) de- ngan tujuan untuk memudahkan desa dalam mengelola keuangan desanya. Siskeudes ini merupakan usaha dan komitmen besar untuk mewujudkan akuntabilitas pengelolaan keuangan desa.

Berdasarkan observasi awal di Kecamatan Kabila peneliti menemukan beberapa masalah yang dihadapi antaranya adalah; 1) kurangnya pelaksanaan bimtek yang dilakukan oleh pemerintah daerah pada setiap aparat desa sehingga berpengaruh pada pengelolaan dana desa; 2) tingkat pendidikan aparatur desa yang besar sebagian besar masih lulusan SMA; 3 ) pengawasan dalam pengelolaan dana desa masih belum berjalan karena masih kurang transparan dengan masyarakat sehingga menimbulkan kecemburuan dalam pengelolaan keuangan desa; 4) sering terjadi keterlambatan laporan keuangan desa; 5) masih lemahnya skill (keterampilan) terkait laporan keuangan.

\section{TINJAUAN PUSTAKA \\ Teori Administrasi Publik}

Menurut Chandler dan Plano dalam ke ban (Tahir 2014:2), mengemukakan bahwa administrasi publik adalah proses dimana sumber daya dan porsenil publik di organisir dan di koordinasikan untuk memformulasikan, mengimplementasikan dan mengelola (manage) keputusan-keputusan dalam kebijkakan publik.

Menurut Nigro dan Nigro (dalam Pasalong, 2016:8) mendefenisikan administrasi publik adalah: 1) suatu kerja sama kelompok dalam lingkungan pemerintahan; 2) meliputi tiga cabang pemerintahan: eksekutif, legislatif, dan serta hubungan diantara mereka; 3) mempunyai peranan penting dalam perumusan kebijakan pemerintah, dan karenanya merupakan sebagian dari proses politik; 4) sangat erat kaitannya dengan berbagai macam kelompok swasta dan perorangan dalam menyajikan pelayanan kepada masyarakat; 5) dalam beberapa hal berbeda pada penempatan pengertian dan administarsi perorangan.

Dari berbagai definisi diatas maka peneliti mencoba merumuskan administrasi 
publik merupakan seluruh upaya penyelenggaraan pemerintah yang aktivitas atau kegiatan yang meliputi aktivitas atau kegiatan manajemen pemerintah dimana mulai dari pengorganisasian, perenanaan, pelaksanaan, pembangunnan, pengawasan melalui mekanisme kerja dan daya dukung dari administrasi itu sendiri. Administrasi juga tidak terpisahkan dengan kehidupan sehari-hari karena manusia merupakan makhluk sosial yang tidak bisa bekerja sendiri serta membutuhkan orang lain dalam pencapaian tujuannya.

\section{Pengertian Kebijakan Publik}

Menurut Nurcholis (Tahir, 2013:7) me mberikan definisi tentang kebijkan sebagai keputusan suatu organisasi yang dimaksudkan untuk mencapai tujuan tertentu, berisikan ketentuan-ketentuan yang dapat dijadikan pedoman perilaku.

Menurut Dunn dalam syafie (2010: 106) bahwa kebijakan publik adalah suatu rangkaian pilihan-pilihan yang saling berhubungan yang dibuat oleh lembaga atau pejabat pemerintah pada bidang-bidang yang menyangkut tugas pemerintahan, seperti pertahanan keamanan, energi, kesehatan, pendididkan, kesejahteraan masyarakat, kriminalitas, perkotaan. Suatu kebijakan yang telah ditetapkan baik dalam hubungan dengan (unit) organisasi pelaksana maupun kelompok dengan kelompok sasaran yang dimaksudkan.

Menurut Singadila dalam Sahya (2012: 499) mendefinisikan bahwa kebijakan publik merupakan keputusan atas sejumlah atau serangkaian pilihan (set of choosing) yang berhubungan satu sama lain yang dimaksud untuk mencapai sasaran/tujuan tertentu. Sedangkan menurut Islamy dalam sahya (2012:501) Kebijakan publik merupakan serangkain tindakan yang ditetapkan dan dilaksanakan atau tidak dilaksanakan oleh pemerintah dengan berorientasi pada tujuan tertentu demi kepentingan seluruh masyarakat.

Kebijakan publik pada dasarnya adalah suatu keputusan yang dimaksudkan untuk mengatasi kesalahan tertentu untuk melakukan kegiatan tertentu, atau untuk mencapai tujuan tertentu yang dilakukan oleh instansi yang mempunyai wewenang dalam rangka penyelenggaraan tugas pemerintahan negara dan pembangunan, berlang sung dalam satu atau beberapa kebijakan tertentu (Mulyadi, 2016:37).

\section{Definisi Evaluasi}

Evaluasi berasal dari bahasa Inggris "evaluation" yang diserap dalam perbendaharaan istilah Indonesia dengan tujuan mempertahankan kata aslinya dengan sedikit penyesuaian lafal Indonesia menjadi "evaluasi". Pengertian evaluasi yang bersumber dari kamus Oxford Advanced Learner's Dictionary of Current English evaluasi adalah to find decide the amount or value yang artinya suatu upaya untuk menentukan suatu nilai.

Evaluasi juga merupakan alat ilmu kedokteran dan ilmu kesehatan lainnya dengan kata lain evaluasi merupakan alat ukur yang ada kaitannya dengan ilmu-ilmu pengetahuan nilai atau jumlah.

Menurut Abidin (Mulyadi, 2016:86), Pengertian evaluasi secara lengkap mencakup tiga pengertian, yaitu:

1. Evaluasi awal, yaitu dari proses perumusan kebijakan sampai saat sebelum diimplementasikan (ex-ante evaluation)

2. Evaluasi dalam proses implementasi atau monitoring.

3. Evaluasi akhir yang dilakukan setelah proses implementasi kebijakan (ex-post evaluation).

Menurut Lester dan Stewart yang di kutip Agustino (Mulyadi, 2016:86), bahwa evaluasi ditujukan untuk melihat sebagiansebagian kegagalan suatu kebijakan dan untuk mengetahui apakah kebijakan yang telah dirumuskan dan dilaksanakan dapat menghasilkan dampak yang diinginkan. Ketika kita akan melakukan evaluasi dari suatu kebijakan, ada banyak hal yang perlu diperhatikan sebelumnya.

\section{Pemerintah Desa}


Pemerintah desa atau disebut juga pemdes adalah lembaga pemerintah yang bertugas mengelola wilayah tingkat desa.

Kewenangan desa meliputi kewenangan di bidang penyelenggaraan pemerintahan desa, pelaksanaan pembangunan desa, pembinaan kemasyarakatan desa, dan pemberdayaan masyarakat desa berdasarkan prakarsa masyarakat, hak asal usul, dan adat istiadat desa (UU No. 6 Tahun 2014 Pasal 18).

Kepala desa selaku penanggungjawab kegiatan pengelolaan alokasi dana desa mempunyai beberapa peranan yang meliputi: a) mengadakan sosialisasi pelaksanaan kegiatan alokasi dana desa; b) membentuk tim pelaksana tingkat desa; c) membuat Daftar Rencana Kegiatan (DRK) alokasi da na desa yang dilakukan bersama lembagalembaga terkait dan tokoh masyarakat, dan d) mendampingi bendahara desa pada saat pencairan alokasi dana desa.

\section{Pengelolaan Keuangan Desa}

Berdasarkan Peraturan Menteri Dalam Negeri Nomor 113 Tahun 2014 tentang Pengelolaan Keuangan Desa menjelaskan bahwa semua penerimaan dan pengeluaran desa dalam rangka pelaksanaan kewenangan desa dilaksanakan melalui rekening kas desa. Peraturan Menteri Dalam Negeri Nomor 113 Tahun 2014 tentang Pengelolaan Keuangan Desa juga menjelaskan bah wa untuk pelaksana kegiatan mengajukan pendanaan untuk melaksanakan kegiatan harus disertai dokumen berupa rencana anggaran biaya yang diverifikasi oleh sekretaris dan disahkan oleh kepala desa.

Menurut Undang-Undang Nomor 6 Ta hun 2014 tentang Desa Pasal 71 Ayat (1), keuangan desa adalah semua hak dan kewajiban desa yang dapat dinilai dengan uang serta segala sesuatu berupa uang dan barang yang berhubungan dengan pelaksanaan hak dan kewajiban desa yang menimbulkan pendapatan, belanja, pembiayaan, dan urusan keuangan.

Berdasarkan Permendagri Nomor 37 Tahun 2007 tentang Pedoman Pengelolaan
Keuangan Desa, belanja desa terdiri dari belanja langsung dan belanja tidak langsung. Belanja langsung merupakan belanja yang dianggarkan terkait secara langsung dengan pelaksanaan program dan kegiatan. Belanja langsung terdiri atas belanja pegawai, belanja barang dan jasa, serta belanja modal desa.

Berdasarkan Peraturan pemerintah No. 43 tahun 2014 tentang desa dalam pasal 93, ayat 1 , pengelolaan keuangan desa meliputi

a. Perencanaan

Perencanaan keuangan desa adalah proses pemikiran dan penentuan secara matang untuk mencapai tujuan dalam peng elolaan keuangan desa dalam hal kegiatan pembangunan maupun pemberdayaan masyarakat

b. Pelaksanaan

Pelaksanaan keuangan desa adalah proses dimana peraturan desa tentang APB Des yang telah ditetapkan sebelumnya dilaksanakan dalam rangka pelaksanaan kegiatan pemerintahan desa dalam pelayanan, pembangunan maupun dalam pemberdayaan masyarakat desa

c. Penatausahaan

Penatausahaan adalah proses dimana semua kegiatan/pelaksanaan keuangan desa dikelola dan dicatat dalam buku-buku tertentu oleh bendahara desa yang sebelumnya telah ditetapkan oleh kepala desa dengan keputusan kepala desa.

d. Laporan

Laporan keungan desa adalah proses hasil kegiatan dari penatausahaan keungan desa dikelola dan disampaikan oleh pemerintah desa kepada BPD, pengawas dan masyarakat.

e. Pertanggungjawaban

Tanggung jawab adalah proses dimana semua kegiatan pengelolaan keuangan desa dipertangungjawabkan oleh pemerintah desa kepada seluruh masyarakat desa dan pihak terkait lainnya pengelolaan keuangan desa tersebut.

\section{Sistem Keuangan Desa (Siskeudes)}


Pengembangan aplikasi Sistem Keuangan Desa telah dipersiapkan sejak awal da lam rangka mengantisipasi penerapan UU Nomor 6 tahun 2014 tentang Desa.

Aplikasi Sistem Keuangan Desa (SISK EUDES) merupakan aplikasi yang di buat oleh BPKP untuk membantu pemerintah de sa dalam pelaporan keuangan desa dengan tujuan yaitu:

- Memastikan seluruh ketentuan dan kebijakan dalam implementasi UU Desa khususnya keuangan dan pembangunan desa dapat dilaksanakan dengan baik untuk seluruh tingkatan pemerintah.

- Pemerintah desa dapat melaksanakan siklus pengelolaan keuangan desa secara akuntabel mulai dari perencanaan, pelaksanaan, penatausahaan, pelaporan, pertanggungjawaban dan pengawasan.

- Pemerintah desa diberikan kesempatan yang besar untuk mengurus tata pemerintahannya sendiri, termasuk pengelolaan keuangannya, serta melaksanakan pembangunan untuk meningkatkan kesejahteraan dan kualitas hidup masyarakat desa.

Secara umum pengelolaan keuangan desa harus berpedoman pada prinsip-prinsip berikut: 1) pengelolaan keuangan direncanakan secara terbuka melalui musyawarah perencanaan pembangunan desa yang hasilnya dituangkan dalam peraturan desa tentang APBDes, serta dilaksanakan dan di evaluasi secara terbuka dan melibatkan seluruh unsur masyarakat desa; 2) seluruh kegiatan harus dapat di pertanggungjawabkan secara administrasi, teknis, dan hukum; 3) informasi tentang keuangan desa secara transparan dapat diperoleh masyarakat; 4) pengelolaan keuangan dilaksanakan dengan prinsip hemat, terarah, terkendali.

Faktor penghambat dan faktor pendukung dalam keuangan desa.

Faktor penghambat:

- Kurangnya sumber daya manusia

- Kurangnya BIMTEK aparat desa

- Sering terjadi keterlambatan laporan Faktor pendukung
- Kemudahan mengakses keuangan desa

- Sarana prasarana cukup lengkap

- Menghasilkan pelaporan keuangan dengan waktu yang telah ditentukan

\section{METODE PENELITIAN}

Penelitian ini menggunakan metode pendekatan kualittif. Penelitian kualitatif adalah penelitian yang menekankan pada quality atau hal yang terpenting dari sifat suatu barang/jasa.

Untuk memperoleh data yang benar dan akurat dalam penelitian ini maka dapat dilakukan dengan cara wawancara mendalam dan observasi.

Teknik wawancara adalah proses tanya jawab dalam penelitian yang berlangsung secara lisan oleh peneliti dengan narasumber untuk memperoleh data.

Menurut Satori dan Komariah (2012: 130), wawancara mendalam dilakukan dalam konteks observasi partisipasi. Peneliti terlibat secara intensif dengan seting penelitian terutama pada keterlibatannya dalam kehidupan informan. Sedangkan observasi pada penelitian ini dilakukan secara pengamatan langsung terhadap objek yang di teliti, berupa kondisi, situasi dan proses. Observasi dalam kamus besar Bahasa Indonesia berarti pengamatan atau peninjauan langsung secara cermat.

Hadi S dalam Sugiyono, (2015:166), mengemukakan bahwa, observasi merupakan suatu proses yang komplek, suatu proses yang tersusun dari berbagai proses biologis dan psikologis. Dua diantara terpenting adalah proses-proses pengamatan dan ingatan.

Dokumentasi merupakan teknik pengumpulan data dengan cara ini biasanya di gunakan untuk mencari data yang bersumber dari berbagai catatan-catatan, transkip, buku, dan tabel-tabel serta foto-foto yang didomunetasikan di lokasi penelitian atau tempat lainnya yang memberikan informasi yang berkaitan dengan masalah yang saat ini diteliti. 


\section{HASIL PENELITIAN}

Berdasarkan analisis hasil penelitian dan pembahasan, dapat diuraikan hasil penelitian sebagai berikut:

\section{Evaluasi Penerapan Sistem Keuangan}

Penerapan sistem keuangan desa sangat penting adanya karena dapat membantu pemerintah desa dalam mengelola keuangan desa menjadi lebih efektif dan efisien. Sistem Keuangan Desa (Siskeudes) di terapkan pada tahun 2017 proses penggunaan aplikasi sistem keuangan desa di Kecamatan Kabila sudah dilaksanakan secara terstruktur dan sesuai prosedur.

Semua laporan keuangan yang sudah selesai akan melewati proses penginputan ke dalam aplikasi sistem keuangan desa. Pengelolaan keuangan desa diperlukan ada nya suatu transparansi dan akuntabilitas yang merupakan suatu bentuk keterbukaan pemerintah desa agar kinerja pemerintahan desa menjadi lebih baik. Jika laporan keuangan desa dapat dilaksanakan dengan baik, maka kinerja pemerintahan desa akan lebih meningkat.

Pemerintah desa diharapkan untuk lebih mandiri dalam mengelola pemerintahan dan berbagai sumber daya alam yang dimiliki, termasuk di dalamnya pengelolaan keuangan dan kekayaan milik desa. Begitu besar peran yang diterima oleh desa, tentunya disertai dengan tanggung jawab yang besar pula. Oleh karena itu pemerintah desa harus bisa menerapkan prinsip transparansi dan akuntabilitas mengingat dalam pengelolaan keuangan desa tersebut.

Pengelolaan keuangan desa diperlukan adanya suatu transparansi dan akuntabilitas yang merupakan suatu bentuk keterbukaan pemerintah desa agar kinerja pemerintahan desa menjadi lebih baik. Jika laporan keuangan desa dapat dilaksanakan dengan baik, maka kinerja pemerintahan desa akan lebih meningkat lagi.

\section{Faktor Penghambat/Pendukung}

Dalam pelaksanaan penerapan sistem keuangan desa (siskeudes) terdapat faktor penghambat dan pendukung yaitu:
Faktor penghambat

\section{- SDM masih minim}

Kemampuan sumber daya manusia berkaitan dengan penyelesaian administrasi. Diketahui bahwa dalam pengelolaan keuangan desa memiliki prosedur mulai dari perencanaan hingga pelaporannya tidak terhindarkan dari penyelesaian urusan administrasi. Untuk itu sangat diperlukan aparatur yang memiliki kemampuan untuk mengelola keuangan desa.

- Kurangnya bimtek bagi aparat desa Kurangnya bimbingan teknis bagi aparat desa mengakibatkan kurangnya pengetahuan tentang pengelolaan alokasi dana desa, sehingga, aparat desa tidak bisa menggerakan masyarakat untuk ikut dalam kegiatan pembangunan desa dengan baik. Hal tersebut menjadikan masyarakat kurang berpartisipasi dalam pengelolaan alokasi dana desa.

- Keterlambatan laporan keuangan Dalam mengelola keuangan desa tidak hanya mengandalkan kuasa kepala desa dan perangkatnya. Tetapi butuh keterlibatan berbagai stakeholders yang ada di desa. Apalagi saat ini desa telah mengelola dana dalam jumlah besar. Untuk itu, desa perlu memiliki orang yang mahir agar membantu menyusun RPJMDes, RKPDes, design \& RAB serta APBDes. Faktor pendukung

- Kemudahan dalam mengakses keuangan desa. Dengan adanya aplikasi siskeudes memudahkan kita dalam mengelola keuangan desa

- Sarana prasarana cukup lengkap dengan tersedianya alat-alat pendukung yang akan membantu aparatur pemerintah desa yaitu dengan adanya komputer, atau jaringan internet untuk mendukung kinerja aparat pemerintah desa.

Menghasilkan pelaporan keuangan dengan waktu yang telah ditentukan maka diperlukan tahapan pelaporan keuangan desa yaitu anggaran yang dibuat terdiri dari 
akun pendapatan, akun belanja, dan akun pembiayaan anggaran.

\section{KESIMPULAN}

Berdasarkan hasil penelitian tentang evaluasi penerapan sistem keuangan desa di Kecamatan Kabila, Kabupaten Bone Bolango sebagai berikut:

1. Penerapan sistem keuangan desa di Kecamatan Kabila Kabupaten Bone Bolango berdampak baik dan mempermudah dalam pengelolaan keuangan. Aplikasi sistem keuangan desa merupakan aplikasi yang baik dan telah menghasilkan kualitas akuntabilitas desa dan mewujudkan tata kelola keuangan desa yang transparan dan akuntabel.

2. Dalam penerapan sistem keuangan desa terdapat faktor penghambat dan faktor pendukung; 1) faktor pendukung yakni kemudahan dalam mengakses keuangan desa, sarana prasarana cukup lengkap, menghasilkan pelaporan keuangan dengan waktu yang telah ditentukan; 2) faktor penghambat yakni, kurangnnya bimtek pada setiap aparat desa, sumber daya manusia yang masih minim, pengawasan dalam pengelolaan dana desa masih belum berjalan karena masih kurang transparan dengan masyarakat, dan sering terjadi keterlambatan laporan keuangan, serta masih lemahnya skill (keterampilan) terkait kreativitas laporan keuangan.

\section{SARAN}

Dari kesimpulan yang diuraikan diatas maka penulis memberikan saran dalam hal pengelolaan keuangan desa antara lain:

1. Diharapkan kepada pemerintah desa di Kecamatan Kabila dapat mempertahankan kinerja yang baik dalam pengelolaan keuangan desa.

2. Pemerintah desa melakukan program pelatihan tentang siskeudes.

3. Pemerintah desa harus transparan dalam pengelolaan keuangan desa.

4. Pemerintah desa perlu meningkatkan pembinaan dan pelatihan kepada aparat tentang pengelolaan keuangan desa.
5. Diharapkan pada pemerintah dapat antisipasi keterlambatan keuangan desa.

\section{DAFTAR PUSTAKA}

Abidin, M. Z. (2015). Tinjauan atas pelaksanaan keuangan desa dalam mendukung kebijakan dana desa. Jurnal Ekonomi \& Kebijakan Publik, 6(1), 61-76.

Arifiyanto, D. F., \& Kurrohman, T. (2014). Akuntabilitas pengelolaan alokasi dana desa di Kabupaten Jember. Jurnal Riset Akuntansi \& Keu, 2(3), 473-485.

Akang, A. (2015). Kesiapan Pemerintah Desa Landungsari Menghadapi Implementasi Alokasi Dana Desa Sesuai Undang-Undang Nomor 6 Tahun 2014. JISIP: Jurnal Ilmu Sosial Ilmu Politik.

Astuti, T. P., \& Yulianto, Y. (2016). Good Governance Pengelolaan Keuangan Desa menyongsong Berlakunya Undang-Undang No.6 Tahun 2014. Berkala akuntansi \& keuangan Indonesia, 1(1).

Fajri, R. (2015). Akuntabilitas Pemerintah Desa pada Pengelolaan Alokasi Dana Desa (Studi Pada Kantor Desa Ketindan, Kecamatan Lawang, Kabupaten Malang). Jurnal Administrasi Publik, 3(7), 1099-1104

Hanifah, S. I., \& Praptoyo, S. (2015). Akun tabilitas dan Transparansi

Husna, S., \& Abdullah, S. (2016). Kesiapan aparatur desa dalam pelaksanaan pe ngelolaan keuangan desa secara akuntabilitas sesuai undang-undang nomor 6 tahun 2014 tentang desa (studi pada beberapa desa di Kabupaten Pidie). Jur nal Ilmiah Mahasiswa Ekonomi Akuntansi, 1(1), 282-293.

Keban, Yeremies T. 2008, "Enam Dimensi Strategis administrasi Publik Konsep, Teori \& Isu". Yogyakarta: Gava Media

Khoiriah, S., \& Meylina, U. (2017). Analisis sistem pengelolaan dana desa berda sarkan regulasi keuangan desa. Masalah-Masalah Hukum, 46(1), 20-29.

Karimah, F. (2014). Pengelolaan Alokasi Dana Desa dalam Pemberdayaan Masyarakat (Studi pada Desa Deket Kulon, Kecamatan Deket, Kabupaten Lamo- 
ngan). Jurnal Administrasi Publik Vol. 2(4), 597-602.

Makalalag, A.J., Nangoi, G \& Karamoy, H. (2017). Akuntabilitas Pengelolaan Dana Desa di Kecamatan Kotamobagu Selatan Kota Kotamobagu. Universitas Samratulangi: Manado.

Mardiasmo, 2002. Akuntansi Sektor Publik. Yogyakarta : Andi

Putriyanti, A. 2012. Penerapan Otonomi Desa Dalam Menguatkan Akuntabilitas Pemerintah Desa Dan Pemberdayaan Masyarakat Di Desa Aglik, Kecamatan Grabag, Kabupaten Puwerjo.

Pasalong, Harbani. 2016 "Teori Administrasi Publik." Bandung: alfabeta.

Pertanggungjawaban Anggaran Pendapatan Belanja Desa (APBDes). Jurnal Ilmu \& Riset Akuntansi, 4(8), 1-15.

Prasetyo, A. G., Muis, A., \& Negara, L. A. (2015). Pengelolaan Keuangan Desa Pasca UU No. 6 Tahun 2014 Tentang Desa: Potensi Permasalahan Dan Solusi. Jurnal Desentralisasi, 13(1), 16-31.

Rahum, A. (2015). Pengelolaan Alokasi Da na Desa (ADD) Dalam Pembangunan Fisik Desa Krayan Makmur Kecamatan Long Ikis Kabupaten Paser. Dalam: Ilmu penelitian, 3(04), 1623-1636. Suarnata, I. W. A., Atmadja, A. T., SE, A., Sulindawati, N.L.G.E., \& SE Ak, M. (2017). Kurangnya Partisipasi Masyarakat dalam Pengelolaan Alokasi Dana desa (Studi Kasus Pada Desa Ma nikliyu Kecamatan Kintamani Kabupaten Bangli). JIMAT (Jurnal Ilmiah Mahasiswa Akuntansi) Undiksha, 8(2).
Riyanto, T. (2015). Akuntabilitas Finansial Dalam Pengelolaan Alokasi Dana De sa (Add) di Kantor Desa Perangat Selatan Kecamatan Marangkayu Kabupaten Kutai Kartanegara. Ejournal Administrasi Negara, 3(1), 199-130.

Sayuti, A. H. Y. (2014). Rekonstruksi Sistem Pengawasan Pemerintahan Desa Berdasarkan Undang-Undang Nomor 6 Tahun 2014 Tentang Desa Berbasis Prinsip Good Village Governance. Kumpulan Jurnal Mahasiswa Fakultas Hukum, 1(1).

Saputra, I. W., Sujana, I. N., Si, M., \& Haris, I. A. (2016). Efektivitas Pengelolaan Alokasi Dana Desa (ADD) Pada De sa Lembean Kecamatan Kintamani $\mathrm{Ka}$ bupaten Bangli Tahun 2009-2014. Jurnal Pend. Ekonomi Undiksha, 6(1).

Tahir, Arifin. 2014. "Kebijkan Publik dan Transparansi penyelenggaraan Pemerintah Daerah." Bandung; Alfabeta.

Taufik, T. (2009). Pengelolaan Keuangan Desa Dalam Sistem Keuangan Negara Republik Indonesia. Jurnal Ekonomi Universitas Riau, 17(01).

Widiyanti A (2017) Akuntabilitas \& Transparansi Pengelolaan Alokasi Dana Desa. Universitas Islam Negeri: Malang.

Undang-Undang Republik Indonesia No. 6 Tahun 2014 Tentang Desa

Undang-Undang Republik Indonesia Nomor 17 tentang keuangan Negara

Permendagri Nomor 113 Tahun 2014 tentang pengelolaan Keuangan Desa 